\title{
Pengawasan dan Tata Laksana Pemeriksaan Kesehatan Ternak Sapi Di Pasar Hewan Babat Dan Tikung Kabupaten Lamongan
}

\author{
Supervision and Inspection of Livestock Health in Babat and Tikung \\ Animal Market Lamongan Regency
}

Moh. Abdur Rosid Al Aziz1, Pudji Srianto², Agung Budianto Achmad ${ }^{3}$

${ }^{1}$ Program Studi DIII Paramedik Veteriner, Departemen Kesehatan, Fakultas Vokasi, Universitas Airlangga, Surabaya-Indonesia

${ }^{2}$ Departemen Reproduksi Veteriner, Fakultas Kedokteran Hewan, Universitas Airlangga, Surabaya-Indonesia

${ }^{3}$ Departemen Kesehatan, Fakultas Vokasi, Universitas Airlangga, Surabaya-Indonesia *email: ab.achmad@vokasi.unair.ac.id

\begin{abstract}
ABSTRAK
Pengawasan dan pemeriksaan kesehatan ternak sangat penting dilakukan di pasar hewan, sebagai upaya pencegahan penyebaran penyakit dan kerugian pada peternak. Penelitian ini bertujuan untuk mengetahui pengawasan dan tata laksana pemeriksaan kesehatan ternak sapi di pasar hewan. Pasar hewan Babat dan Tikung merupakan unit pelaksana teknis yang dikelola oleh Perusahaan Umum Daerah Kabupaten Lamongan yang memiliki sarana penunjang antara lain timbangan ternak, pusat kesehatan hewan, administrasi, dan sistem transportasi. Pengambilan data dilakukan secara observatif dengan melakukan pengamatan di kedua lokasi pasar pada bulan Februari - Maret 2020. Ternak sapi yang dipasarkan pada hari operasional pasar berjumlah 200 sampai 500 ekor. Berdasarkan data formulir lalu lintas ternak yang didapat melalui kontrol keliling yang dilakukan oleh dokter hewan menunjukkan bahwa sapi yang dipasarkan dalam keadaan sehat. Hasil pengamatan menunjukkan bahwa pengawasan dan pemeriksaan kesehatan ternak di pasar hewan Babat dan Tikung belum dilakukan secara optimal karena hanya dilakukan melalui kontrol keliling tanpa menggunakan alat-alat pendukung seperti stetoskop dan termometer.
\end{abstract}

Kata kunci: Kesehatan ternak, pasar hewan, sapi potong 
ABSTRACT

Supervision and inspection of livestock health is very important to do in the animal market, as an effort to prevent the spread of disease and losses to farmers. The aim of this study is to know the The Babat and Tikung animal market are technical implementation unit managed by the supervision and inspection of livestock health in animal market. Lamongan District Public Company that has supporting facilities including livestock scales, animal health centers, administration and transportation systems. Data was collected by observing at both market locations in February - March 2020. Cattle which are marketed on market operational days were 200 to 500 species. Based on data from livestock traffic forms obtained through mobile control conducted by veterinarians, cattle are marketed in good health. Supervision and inspection of livestock are on the authority of the veterinarians. Observations indicate that supervision and inspection of livestock health in the Babat and Tikung animal markets has not been carried out optimally because it is only done visually without using supporting tools such as a stethoscope and thermometer.

Keywords: Livestock health, animal market, beef cattle

\section{PENDAHULUAN}

Sapi potong merupakan hewan ternak yang memiliki kontribusi besar dalam kebutuhan pangan di Indonesia, khususnya dalam memenuhi kebutuhan protein hewani. Permintaan kebutuhan daging sapi ini diperkirakan akan terus meningkat seiring dengan kesadaran masyarakat akan pentingnya kebutuhan protein hewani dalam memenuhi kebutuhan gizi tubuh (Susanti et al., 2017). Peternakan yang mendominasi Indonesia yaitu peternakan rakyat yang memiliki skala kecil. Selain sapi potong, di Indonesia juga berkenbang usaha peternakan sapi perah. Frisien Holsein merupakan jenis sapi perah yang bsnysk dibudidayakan di Indonesi (Aisyah, 2011)

$$
\text { Sektor peternakan juga }
$$
mempunyai kontribusi yang besar bagi daerah terutama dalam menumbuhkan peluang ekonomi pedesaan (Waris et al., 2015). Pola pemeliharaan ternak ternak di Indonesia memiliki 
karakteristik sebagai berikut : (1) Ratarata kepemilikan rendah; (2) Ternak digunakan sebagai tabungan hidup; (3) Ternak dipelihara dalam pemukiman padat penduduk dan dikandangkan di belakang rumah; (4) Terbatas lahan pemeliharaan sehingga pakan harus dicari di kawasan yang seringkali jauh dari rumah; (5) Usaha ternak dilakukan secara turun temurun; (6) Jika tidak ada modal membeli, peternak manggaduh dengan pola bagi hasil (Zakiah et al., 2017).

Pasar hewan adalah sarana jual beli ternak antara peternak/pedagang dan konsumen. Hewan adalah komoditas yang umumnya tidak mampu untuk didistribusikan sepanjang tahun karena: a) musiman, b) sangat sensitif terhadap cuaca, penyakit, dan c) pada dasarnya terdapat dalam jumlah yang sangat besar dalam sistem produksi dan sistem distribusi tetapi sangat sedikit dalam sistem pengolahan.

Pasar Hewan Babat dan Tikung merupakan Unit Pelaksana Teknis (UPT) Perusahaan Umum Daerah Kabupaten Lamongan yang bekerjasama dengan Dinas Peternakan dan Kesehatan Hewan Kabupaten Lamongan yang menyediakan pusat kesehatan hewan (puskeswan) dan petugas kesehatan hewan (keswan) di setiap pasar. Petugas keswan memiliki peran penting dalam pengawasan dan pemeriksaan kesehatan ternak sapi guna mencegah penyebaran penyakit serta memberikan keuntungan kepada konsumen atau pembeli ternak, karena kondisi ternak yang buruk atau terjangkit suatu penyakit akan menimbulkan kerugian bagi peternak di kemudian hari.

\section{MATERIAL DAN METODE}

Penelitian dilakukan secara observatif yaitu pengamatan dengan cermat dan menyeluruh pada lokasi penelitian di Pasar Hewan Babat dan Tikung yang dilakukan mulai tanggal 24 Februari 2020 sampai dengan tanggal 6 Maret 2020. Selain itu pengumpulan data juga dilakukan melalui studi pustaka dan wawancara. Studi pustaka ini adalah dengan mengutip data yang relevan dengan kekhususan jual beli ternak 
yang harus dilakukan di pasar hrewan sesuai dengan Peraturan Daerah Kabupaten Lamongan Nomor 7 Tahun 2019 tentang Perusahaan Umum Daerah Pasar. Sedangkan wawancara dilakukan dengan interaksi secara verbal dengan dua petugas pasar, satu petugas kesehatan hewan, dua pedagang sapi, dan dua calo ternak terkait kondisi dan kegiatan di pasar hewan. Dengan pertanyaan yang meliputi sistem penjualan, retribusi, pemeriksaan kesehatan ternak, tata laksana pemeriksaan kesehatan ternak, dan jumlah ternak yang dipasarkan.

\section{HASIL}

Pasar hewan Babat dan Tikung merupakan Unit Pelaksana Teknis (UPT) yang dikelola oleh Perusahaan Umum Daerah Kabupaten Lamongan. UPT ini didukung sarana dan prasarana penting antara lain timbangan ternak, pusat kesehatan hewan, administrasi, dan sistem transpostasi. Timbangan ternak di pasar hewan belum dimanfaatkan secara optimal, karena penjualan ternak menggunakan sistem taksiran bobot badan. Ternak yang dipasarkan berasal dari beberapa daerah antara lain Nganjuk, Bojonegoro, Balongpanggang, Modo, dan Ngimbang yang kebanyakan tidak dibawa oleh peternak sendiri, melainkan calo ternak/blantik. Pemeriksaan kesehatan ternak di pasar hewan dilakukan oleh dokter hewan dengan cara kontrol keliling

Tabel 1. Data lalu lintas ternak

\begin{tabular}{cccccc}
\hline NO & $\begin{array}{c}\text { NAMA } \\
\text { PETERNAK }\end{array}$ & $\begin{array}{c}\text { JUMLAH } \\
\text { TERNAK }\end{array}$ & ASAL & TUJUAN & KONDISI \\
\hline 1 & H. Imam & 7 & Nganjuk & Babat & Sehat \\
2 & H. Ridho & 17 & Babat & Lamongan & Sehat \\
3 & H. Toyo & 18 & Nganjuk & Bojonegoro & Sehat \\
4 & H. Saidi & 6 & Modo & Babat & Sehat \\
5 & Banu & 9 & Mantup & Babat & Sehat \\
6 & Hariono & 11 & Babat & Kedungpring & Sehat \\
7 & Makmur & 5 & Ngimbang & Babat & Sehat \\
\hline
\end{tabular}

\section{PEMBAHASAN}

Pasar Hewan Babat dan Tikung merupakan Unit Pelaksana Teknis (UPT) Perusahaan Dagang Kabupaten Lamongan. Kedua pasar tersebut telah berdiri lama dengan skala kecil dan sarana prasarana yang sangat kurang memadai. Namun, seiring berjalannya waktu terus dilakukan perbaikan dan pembangunan pada sarana dan 
prasarana untuk menunjang berjalannya kegiatan jual beli. Sarana dan prasarana merupakan faktor pendukung yang sangat penting dalam keberlangsungan setiap kegiatan (Nasrudin and Maryadi, 2018).

Sarana adalah segala sesuatu yang dapat dipakai sebagai alat dalam mencapai maksud atau tujuan, alat, dan media. Sedangkan prasarana adalah segala sesuatu yang merupakan penunjang utama terselenggaranya suatu proses (usaha, pembangunan, proyek, dan sebagainya). Selain memiliki tempat atau lahan sebagai sarana utama yaitu tempat kegiatan jual beli ternak. Pasar hewan Babat dan Tikung memiliki beberapa sarana dan prasarana pendukung antara lain: timbangan ternak, pusat kesehatan hewan (Puskeswan), administrasi, dan sistem transportasi.

Timbangan ternak merupakan alat ukur untuk mengetahui bobot badan ternak sapi potong. Adanya alat ini untuk memfasilitasi kegiatan jual beli sapi potong dengan sistem timbangan.
Namun, keberadaan timbangan ternak di pasar hewan Babat dan Tikung Lamongan sudah tidak difungsikan sebagai mana mestinya. Hal ini dikarenakan sistem jual beli ternak sapi potong di kedua pasar tersebut tidak menggunakan sistem timbangan, melainkan sistem taksiran. Sistem taksiran merupakan sistem penjualan dengan menaksir bobot badan ternak dengan melihat dan meraba tubuh ternak. Sistem ini didasarkan pada pengalaman pedagang maupun calo ternak yang sebagian besar telah lama menjalani usaha jual beli ternak.

Puskeswan adalah Pos Kesehatan Hewan yang memberikan pelayanan di bidang kesehatan hewan. Puskeswan mutlak dibutuhkan di pasar hewan yang memiliki skala besar untuk menjalankan fungsi pengawasan kesehatan ternak, karena berhubungan dengan lalu lintas ternak antar daerah. Puskeswan menyediakan atau memfasilitasi pengadaan surat keterangan kesehatan hewan (SKKH) untuk ternak yang dikirim antar provinsi. 
Pemeriksaan kesehatan ternak di pasar hewan Babat dan Tikung dilakukan oleh petugas atau dokter hewan yang yang ditunjuk oleh Dinas Peternakan dan Kesehatan Hewan Kabupaten Lamongan. Pemeriksaan dilakukan dengan cara kontrol keliling untuk melihat kondisi ternak. Selain melakukan pemeriksaan kesehatan ternak dokter hewan puskeswan juga memiliki wewenang untuk melakukan pemeriksaan kebuntingan (PKB).

Masalah yang sering dihadapi oleh dokter hewan di pasar hewan yaitu kebiasaan para penjual yang cenderung menolak adanya pemeriksaan kesehatan ternak dan pemeriksaan kebuntingan. Mereka menilai kegiatan tersebut akan menghabiskan banyak waktu dan juga akan mempengaruhi calon pembeli jika mengetahui kondisi ternak yang kurang baik. Selain itu, masalah yang sering terjadi yaitu banyaknya sapi betina yang diklaim bunting oleh penjual dan calo ternak. Metode pemeriksaan kebuntingan yang dilakukan oleh penjual dan calo ternak yaitu dengan indikator susu yang dilakukan dengan memerah putting sapi. Jika tekstur susu lengket seperti lem, maka sapi diklaim bunting. Pemeriksaan kebuntingan dengan metode tersebut tidak dibenarkan adanya. Belum ada dasar teori yang mendukung metode tersebut, serta dapat memicu terjadinya mastitis dikarenakan kurangnya penerapan aseptis saat pemerahan.

Administrasi adalah usaha atau kegiatan yang berkenaan dengan penyelenggaraan kebijaksanaan untuk mencapai tujuan (Lina Marliani, 2019). Administrasi selalu dijumpai dalam setiap aspek kehidupan manusia. Salah satunya di pasar hewan Babat dan Tikung Kabupaten Lamongan. Sebagai tempat penyelenggaraan perdagangan atau jual beli, pasar hewan Babat dan Tikung menerapkan administrasi dengan penarikan biaya retribusi kepada penjual yang memperdagangkan ternaknya. Adapun biaya retribusi sapi potong di pasar hewan Babat dan Tikung yaitu sebesar Rp. 7.500 per ekor jika sapi laku atau terbeli sedangkan pada sapi yang tidak terbeli maka penjual 
dikenakan biaya retribusi sebesar $\mathrm{Rp}$ 5000 per ekor.

Transportasi merupakan kegiatan memindahkan suatu komoditas atau muatan ke tempat lain. Kualitas ternak dan kesejahteraan hewan sangat bergantung pada transportasi. Buruknya sistem transportasi dapat mempengaruhi beberapa hal antara lain :

Penurunan kualitas daging, menyebabkan ternak stress karena merasa ketakutan, menyebabkan kekurangan cairan atau dehidrasi sebab tidak tersedianya air, dan dapat menyebabkan kembung (Winarso, 2010).

$\begin{array}{rcr}\text { Moda } & \text { transportasi } & \text { yang } \\ \text { digunakan } & \text { dalam } & \text { proses }\end{array}$
pengangkutan ternak di Pasar hewan Babat dan Tikung Kabupaten Lamongan antara lain: truk sedang dan mobil kecil bak terbuka.

Proses penyaluran atau pengiriman ternak sapi potong dari pasar ke daerah konsumen dapat dilakukan menggunakan truk ukuran sedang. Truk ukuran sedang memiliki kapasitas pengangkutan 10 sampai 14 ekor sapi kecil (pedet). Alat angkut truk ukuran sedang memiliki ongkos sewa yang terjangkau.

Mobil bak terbuka umumnya digunakan untuk mengangkut ternak sapi yang menempuh jarak dekat (<100 km). Mobil bak terbuka yang digunakan umumnya bermerk Mitsubishi L-300, dengan daya tampung 4 sampai 10 ekor sapi yang memiliki ukuran kecil sampai sedang.

Operasional kegiatan jual beli ternak sapi potong dilakukan setiap hari Selasa di pasar hewan Babat dan setiap hari Minggu di pasar hewan Tikung. Sapi yang diperdagangkan di pasar hewan Babat berasal dari daerah Bojonegoro, Kedungpring, Nganjuk, Modo, Babat, Krian, dan Balongpanggang. Ternak yang berasal dari wilayah cukup jauh dari pasar umumnya mulai masuk pasar atau dropping satu hari sebelumnya, sedangkan yang berjarak dekat memulai dropping antara pukul 07.00 09.00 WIB pada hari operasional

Alur transaksi jual beli ternak di unit pasar hewan Babat dan Tikung 
dapat dilihat pada gambar berikut: Pedagang yang membawa sapi masuk ke dalam pasar wajib lapor kepada petugas pasar untuk mendapat kartu retribusi sebagai tanda masuk. Kemudian dilakukan dropping atau penempatan ternak di pengikatpengikat yang telah disediakan oleh pasar agar pembeli dapat leluasa melihat ternak secara leluasa sehingga mempermudah transaksi jual beli. Setelah proses jual beli usai ternak kemBali diangkut keluar pasar untuk dikirim ke alamat pembeli.

\section{KESIMPULAN}

Hasil penelitian menunjukkan bahwa pengawasan dan pemeriksaan kesehatan ternak di pasar hewan Babat dan Tikung belum dilakukan secara optimal karena hanya dilakukan tanpa menggunakan alatalat pendukung seperti stetoskop dan termometer.

\section{DAFTAR PUSTAKA}

Aisyah, S., 2011. Tingkat Produksi Susu Dan Kesehatan Sapi Perah Dengan Pemberian Aloe Barbadensis Miller. Gamma 7, 50-60.
Lina Marliani, M.S., 2019. Definisi Administrasi Dalam Berbagai Sudut Pandang. J. Chem. Inf. Model. 53, 1689-1699.

Nasrudin, Maryadi, 2018. Manajemen Sarana dan Prasarana Pendidikan dalam Pembelajaran di SD. J. Manag. Pendidik. 13, 15-23.

Susanti, Y., Priyarsono, D.S., Mulatsih, S., 2017. Pengembangan Peternakan Sapi Potong untuk Peningkatan Perekonomian Provinsi Jawa Tengah: Suatu Pendekatan Perencanaan Wilayah. J. Agribisnis Indones. 2, 177 .

Waris, Badriyah, N., A., D.W., 2015. Pengaruh tingkat pendidikan, usia dan lama beternak terhadap pengetahuan manajeman reproduksi ternak sapi potong di Desa Kedungpring Kecamatan Balongpanggang Kabupaten Gresik. J. Ternak 06, 30-33.

Winarso, B., 2010. Peran Sarana Angkutan Darat Dalam Upaya Peningkatan Efisiensi Distribusi Ternak Dan Hasil Ternak Sapi Potong Di Indonesia Means of Land Transport role In Improving Efficiency Distribution of Livestock and Cattle Product In Indonesia Bambang Winarso 15, 125-137.

Zakiah, Z., Saleh, A., Matindas, K., 
2017. Gaya Kepemimpinan dan Perilaku Komunikasi GPPT dengan Kapasitas Kelembagaan Sekolah Peternakan Rakyat di Kabupaten Muara Enim. J. Penyul. 13, 133. 